\title{
MONEY, CREDIT, HOUSE PRICES AND QUANTITATIVE EASING - THE WAVELET PERSPECTIVE FROM 1970 TO 2016
}

\author{
Maciej RYCZKOWSKI (D)* \\ Faculty of Economic Sciences and Management, \\ Nicolaus Copernicus University in Toruń, Poland \\ Received 09 December 2018; accepted 04 March 2019
}

\begin{abstract}
This paper investigates the relationship between money/credit growth and house price inflation for a sample of twelve developed countries. The novel application of the continuous wavelet transform showed significant but time-varying linkages between these two variables. During quantitative easing in the United States and the United Kingdom, growth of respectively broad money and bank credit was leading house price inflation for the 2-8 years cycle. In contrast to this, the Bank of Japan and the European Central Bank either did not assign a separate role to house prices in their reaction functions or the two central banks were not capable to significantly increase house prices by extending money/credit during the business cycle. The significant co-movements of financial variables and house prices around booming episodes warn us that a new asset price boom might appear within the length of a business cycle as a consequence of overly expansionary monetary policy. In the euro area, the significant, long run, and close to a one-for-one link between growth of M3 and house price inflation is an argument for the monetary pillar of the European Central Bank. The present study contributes significantly to the literature by introducing a novel application of a continuous wavelet transform to study the housing prices in relation to money, credit and quantitative easing. The article uses a long-term dataset covering a period of almost half a century to analyse their varying relationship in the short-run to the long-run and from the historical perspective.
\end{abstract}

Keywords: money and house prices, credit and house prices, wavelets, historical co-movements, quantitative easing, asset price booms.

JEL Classification: C22, E32, E44, E5.

\section{Introduction}

The Great Recession may be traced back to the negative housing shocks (Prieto, Eickmeier, \& Marcellino, 2016). Housing related recessions renewed interest in the linkages between housing and macroeconomic variables. The goal of this article is to add new wavelet perspective on the historical co-movements between money/credit growth and house price inflation, the prevailing causality, the importance of money and credit in influencing house prices (or con-

*Corresponding author. E-mail: m_ryczkowski@umk.pl 
versely) and to disentangle the short (high frequency) and long-run (low frequency) effects. ${ }^{1}$ The article employs a Continuous Wavelet Transform (CWT) to analyse the changes in the short-run (up to one year) to the long-run (up to 24 years). Moreover, CWT simultaneously presents how the relationship changed over time from the "monetarism era", through the emergence of inflation targeting regimes and the Great Recession separately for each country. The study applies the wavelet coherence, phase differences and the wavelet gain to investigate the assumedly varying interconnectedness between money/credit and housing prices during normal times, during housing bubble periods and during quantitative easing. These kinds of interrelations are hard to understand using pure time-domain or pure frequencydomain methods (Hkiri, Hammoudeh, Aloui, \& Shahbaz, 2018). Furthermore, the literature analysing the frequency perspective frequently rests on arbitrary cut-off of the frequency bands. Continuous wavelet analysis avoids this problem by providing for the continuous and simultaneous decomposition of money/credit growth and house price inflation on the time and frequency space to find the time-varying spectral features. The topic of the article corresponds to a contemporary debate on the role played by money and credit in monetary policy and in creating financial instability.

The unprecedented responses of major central banks and the severity of the Great Recession constitute a natural background to study the impact of quantitative easing (QE) on money, credit and house prices. In particular, the relevance of the housing sector for the business cycle raise important questions for policymakers and academics. Notably, one may be interested if unconventionally large purchases of public and private debt securities matter for asset prices (see, Belke, Orth, \& Setzer, 2008) or could propagate a new boom (Taylor, 2009; Thornton, 2010). Despite that, the majority of literature has measured QE's effectiveness by its impact on interest rates. Meanwhile, unconventional asset purchases should increase the amount of money and credit in the economy. Therefore, special emphasis in the interpretation of the results was put on analysing the extent to which money and credit developments affected house prices in the short and longer-run in the main advanced economies during QE.

The present study contributes significantly to the literature by introducing a novel application of a continuous wavelet transform to study the housing prices in relation to money, credit and QE. As opposed to the wavelet methodology, majority of the studies on the subject of money/credit versus house prices explore the link only in one direction or do not take into account the fact that the relation changes in time and for a given time horizon. Moreover, wavelet phase spectrum has advantage over the conventional Granger causality test because the latter one assumes that a single causal link is present for the whole investigated time span and at each frequency (Grinsted, Moore, \& Jevrejeva, 2004). This means that the current literature is missing many benefits of using CWT to analyse the co-movements and leadlag pattern across time and frequency between money/credit and house prices. Moreover, most articles applying the wavelet approach avoid international comparisons. Meanwhile, the diversified groups of countries constitute an interesting setup to discover the general and country-specific patterns. In particular, the paper contributes to the literature as it uses

\footnotetext{
1 The considered countries are Australia (AU), Canada (CA), Denmark (DK), the Euro Area (EA), Japan (JP), New Zealand (NZ), Norway (NO), Sweden (SE), South Africa (ZA), Switzerland (CH), the United Kingdom (UK), and the United States (US). Quantitative easing to an unconventional scale was adapted in the US, in the UK, JP and the EA.
} 
an almost half a century long data to account for the varying short-run and long-run interdependencies so that economic forecasters with different operational horizons could adjust their decisions accordingly.

Wavelets delivered fresh results on the behaviour of money and credit during quantitative easing from the perspective of time and frequency-domain. In the US and the UK, growth of respectively broad money and bank credit was leading house price inflation for the 2-8 years cycle. In contrast to this, the Bank of Japan and the European Central Bank either did not assign a separate role to house prices in their reaction functions or the two central banks were not capable to significantly increase house prices by extending money/credit during the business cycle. The diversified patterns in the co-movements between money/credit and house price inflation during QE coincided with macroeconomic performance, which may have relevant implications for monetary policy or for its evaluation.

The morale of the story is that the correlations between money/credit growth and house price inflation rise during the episodes of booming house prices in all of the countries investigated. Notwithstanding this, money/credit developments follow house price dynamics most of the time since the beginning of the Great Moderation. The evidence suggests strong wealth effects and "irrational exuberance" during booming house prices. On the basis of CWT findings, it can be concluded that central banks should carefully monitor house prices in order to react to the emerging financial imbalances by increasing restrictions on lending in order to mitigate their adverse longer-run consequences. This conclusion seems to be especially important for the euro area. In the euro area, the significant, long run, positive, almost instantaneous and close to a one-for-one link between growth of M3 and house price inflation is an argument for the monetary pillar of the European Central Bank. In line with these findings, M3 in the euro area may deliver useful information about future inflation dynamics in the housing sector.

In the last few years defining money has become a difficult empirical task due to the financial innovations and money endogeneity. To solve this problem and to robustify the findings, the article investigates various definitions and versions of money and credit. The article considers M3, M2, bank credit and credit from all sectors. Additionally, the study evaluates how the results change when adjusting monetary growth rates for the rates of real GDP growth to account for the expected linkage between liquidity and the size of a real economy. Finally, the problematic issue concerned the typically diversified international definitions of financial variables, which is especially relevant in case of house price statistics. The problem was solved by using a single house price database of the Bank for International Settlements, where the definitions were harmonised in line with the recommendations from the internationally agreed framework for classifying property price issues.

The article is organized as follows. Section 1 discusses the literature review on the linkage between money/credit and house prices. The section emphasizes the importance of the investigated relationship for the monetary policy and macroeconomic stability at first. Section 2 describes the data, followed by the wavelet methodology in the 3rd section. Section 4 presents empirical results of the wavelet coherence, phase angle and the estimates of the gain coefficients in case of M3 and M2 monetary aggregates, bank credit and credit from all sectors during normal times, around house price boom episodes and during quantitative easing. 
The results are discussed in greater detail for those economies where assets were purchased by central banks to an unprecedented scale.

\section{Literature review}

The link between the housing market and monetary/credit market conditions has recently received much attention in literature. The reason is its high relevance for the regulatory authorities and the macro-prudential policy due to the key role of the housing sector and the associated role played by credit or money dynamics in explaining the 2007-2009 global financial crisis. Indeed, Leamer (2015) shows that housing drives the business cycle. As much as 9 out of the 11 U.S. recessions since 1950 were preceded by declines in housing. In turn, the growing complexity of financial markets may translate into dire economic and social consequences of a burst of a house price bubble (see, Pintér, 2018), which the subprime crisis has proved in retrospect. During a housing bust, construction, consumption and lending rapidly fall down with negative implications for the real GDP growth and unemployment. Banks, financial institutions, companies and households are to delever, while this process may take a long period of time. Additionally, adverse selection and moral hazard may further limit the amount of granted loans, while banks aim to decrease the exposure to the banking system or to contain their indebtedness ratios (see, Dursun-de Neef, 2018). Ultimately, the rise of unemployment rate may be persistent (Ernst \& Saliba, 2018). All of this makes it necessary to monitor house price dynamics as well other factors, in particular, lending and liquidity, both closely related to house price developments. It may help to intervene and to prevent their stock from becoming excessive. The relevance of such an approach is the more important as housing prices may diverge from their long-run equilibrium for a long period of time with relevant consequences for the macro-economy and financial stability. As opposed to that, models without money or credit have neither predicted nor explained the crisis, while the role of the financial sector in its propagation and origination is undeniable.

Indeed, both the pre and post Great Recession works, for example, of Gunn (2018), Gerdesmeier, Reimers, and Roffia (2010), Adalid and Detken (2007), Bordo and Haubrich (2010), Bernanke, Gertler, and Gilchrist (1999) and Borio and Lowe (2004) show that money growth shocks during the pre-boom and boom phases may explain the depth of the postboom recessions, while sizeable growth of money and credit often precedes house price booms. Ferrero (2015) demonstrated that domestic credit can create a house price boom. Alternatively, studies show that higher house prices are related to larger money holdings (Setzer, van den Noord, \& Wolff, 2011), money growth above the model's threshold (Chen, Chang, Yang, \& Hsieh, 2012), excessive monetary growth (Zhang, 2013) and money illusion (Fairchild, Ma, \& Wu, 2015). The money neutrality hypothesis is rejected not only in advanced economies. Simionescu, Balcerzak, Bilan, and Kotásková (2018) find a cointegration between M3, GDP and internal credit in the two following post-transformation Central European economies: Romania and the Czech Republic. Similarly, Osińska, T. Kufel, Błażejowski, and P. Kufel, (2018) identify a considerable role played by the monetary mechanism in diagnosing the phases of a business cycle in most of the European economies. In sum, it is generally well documented that asset price booms were often preceded by rapid expansions of money 
and credit (Jordà, Schularick, \& Taylor, 2015). In turn, other authors proved the causality in the opposite direction. Ramcharan and Crowe (2013) evidenced that asset price fluctuations may determine credit conditions and may propagate a macroeconomics shock, while Baharumshah and Soon (2015) demonstrated that housing prices have a sizeable and significant impact on the demand for broad money. A certain compromise between the two distinctive results is the article of Anundsen and Jansen (2013) who found self-reinforcing effects between house prices and credit.

Despite the amount of evidence on the relationship between money/credit and house price inflation is large (Table 1), numerous authors use the popular VAR or DSGE models in their considerations. Meanwhile, it is hard to understand the relationship between money/credit and house prices across time and operational horizons by applying such models. Indeed, the interrelationship and the direction of causality between the financial and real business cycles may change across frequency (Bruzda, 2017). For example, Willen (2015) expressed doubt whether any general equilibrium model is able to explain the house price bust during the Great Recession of 2007-2009. Although the continuous wavelet transform is efficient in identifying damping in dynamic systems, no wavelet study was applied to investigate the historical link between money/credit on the one hand and house prices on the other hand. ${ }^{2}$ The paper contributes by filling this gap. The novel application of the wavelets may shed new light on the time and frequency-varying relationship, which can be helpful, among others, to construct models augmented with money/credit variables. Despite post Great Recession studies favour the inclusion of money, credit or asset markets into macroeconomic models, the way it should be done still constitutes a challenge (Willen, 2015).

Table 1. Money/credit vs. house prices - a literature review (source: own work)

\begin{tabular}{|l|l|l|l|}
\hline Authorship & \multicolumn{1}{|c|}{ Findings } & \multicolumn{1}{|c|}{$\begin{array}{c}\text { Country/ } \\
\text { region/market }\end{array}$} & \multicolumn{1}{|c|}{$\begin{array}{c}\text { Years/ } \\
\text { Period }\end{array}$} \\
\hline $\begin{array}{l}\text { Dursun-de } \\
\text { Neef (2018) }\end{array}$ & $\begin{array}{l}\text { The reduction in loan supply by banks transmits the } \\
\text { negative liquidity shock to the real economy, which } \\
\text { lowers house prices according to the results of different } \\
\text { empirical models, including the GARCH model and the } \\
\text { DCC model by Engle (2002). }\end{array}$ & $\begin{array}{l}\text { Banks in the } \\
\text { US }\end{array}$ & $\begin{array}{l}\text { the 2007- } \\
2009 \\
\text { Great } \\
\text { Recession }\end{array}$ \\
\hline $\begin{array}{l}\text { Zhang } \\
\text { (2013) }\end{array}$ & $\begin{array}{l}\text { Author uses simple linear and panel data models and } \\
\text { finds that high monetary growth drives excess demand } \\
\text { and house prices. }\end{array}$ & China & 1998-2009 \\
\hline $\begin{array}{l}\text { Su, Wang, } \\
\text { Tao, and } \\
\text { Chang } \\
\text { (2019) }\end{array}$ & $\begin{array}{l}\text { Money supply and housing prices exhibit bidirectional } \\
\text { causal link. Money supply has a positive impact on } \\
\text { housing prices, whereas housing prices affect money } \\
\text { supply both positively and negatively depending on } \\
\text { the analysed sub-period. Authors used a dynamic } \\
\text { equilibrium model. }\end{array}$ & China & $1998-2016$ \\
\hline
\end{tabular}

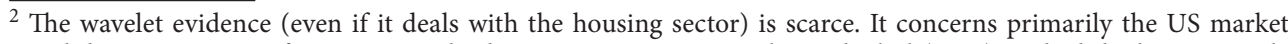
and does not account for money/credit dynamics. For instance, Flor and Klarl (2017) studied the housing cycle synchronization across the largest US metropolitan statistical areas. Su, Yao, and Chang (2016) investigated the relationship between output and asset prices, while Tiwari, Albulescu, and Gupta (2016) examined the link between business cycles, commodity and asset prices. Bruzda (2017) applied real and complex wavelets in asset classification for the US stock market.
} 
End of Table 1

\begin{tabular}{|c|c|c|c|}
\hline Authorship & Findings & $\begin{array}{c}\text { Country/ } \\
\text { region/market }\end{array}$ & $\begin{array}{l}\text { Years/ } \\
\text { Period }\end{array}$ \\
\hline \begin{tabular}{l|} 
Cesa- \\
Bianchi, \\
Cespedes, \\
and Rebucci \\
$(2015)$
\end{tabular} & $\begin{array}{l}\text { Authors employ a PVAR model and find that global } \\
\text { liquidity shock (used as a proxy for the international } \\
\text { supply of credit) has an impact on house prices and } \\
\text { consumption much stronger in emerging markets than } \\
\text { in the advanced economies. }\end{array}$ & $\begin{array}{l}33 \text { emerging } \\
\text { markets and } \\
24 \text { advanced } \\
\text { economies }\end{array}$ & 1990-2012 \\
\hline $\begin{array}{l}\text { Ramcharan } \\
\text { and Crowe } \\
(2013)\end{array}$ & $\begin{array}{l}\text { House price fluctuations can have a significant } \\
\text { and important impact on credit availability and on } \\
\text { determining credit conditions according to different } \\
\text { specifications of linear models. }\end{array}$ & $\begin{array}{l}\text { Prosper.com - } \\
\text { a peer to peer } \\
\text { (P2P) credit } \\
\text { market on the } \\
\text { internet }\end{array}$ & 2006-2008 \\
\hline $\begin{array}{l}\text { Goodhart } \\
\text { and } \\
\text { Hoffman } \\
\text { (2008) }\end{array}$ & $\begin{array}{l}\text { House prices and monetary variables are } \\
\text { interdependent, while their relationship is stronger } \\
\text { over the more recent sub-sample from } 1985 \text { to } 2006 \\
\text { and when house prices are booming. The results were } \\
\text { obtained by employing a fixed-effects panel VAR. }\end{array}$ & $\begin{array}{l}17 \\
\text { industrialized } \\
\text { countries }\end{array}$ & $1970-2006$ \\
\hline $\begin{array}{l}\text { Robstad } \\
(2017)\end{array}$ & $\begin{array}{l}\text { Monetary policy shock has a large impact on house } \\
\text { prices but a muted impact on household credit in line } \\
\text { with the estimated structural VAR models. }\end{array}$ & Norway & 1994-2013 \\
\hline $\begin{array}{l}\text { Kelly, } \\
\text { McCann, } \\
\text { and O’Toole } \\
(2018)\end{array}$ & $\begin{array}{l}\text { A property-level house price model shows that a ten } \\
\text { per cent increase in credit available translates into a } 1.5 \\
\text { per cent rise in the value of property purchased. }\end{array}$ & Ireland & 2003-2010 \\
\hline $\begin{array}{l}\text { Duca, } \\
\text { Muellbauer, } \\
\text { and } \\
\text { Murphy } \\
\text { (2011) }\end{array}$ & $\begin{array}{l}\text { The omission of the dynamics in the mortgage credit } \\
\text { supply in most of the US house price models makes } \\
\text { those models do not fit the reality. When the authors } \\
\text { adjusted house price-to-rent ratio models with data on } \\
\text { credit constraints, they obtained improved model fits, } \\
\text { precisely estimated effects and generally reasonable } \\
\text { results. }\end{array}$ & US & 1980-2007 \\
\hline $\begin{array}{l}\text { Jin and } \\
\text { Zeng (2004) }\end{array}$ & $\begin{array}{l}\text { Money shocks translate to a large extent into volatile } \\
\text { house prices and investment according to a three-sector } \\
\text { quantitative dynamic stochastic general equilibrium } \\
\text { model. }\end{array}$ & US & 1948-1977 \\
\hline $\begin{array}{l}\text { Aoki, } \\
\text { Proudman, } \\
\text { and Vlieghe } \\
(2004)\end{array}$ & $\begin{array}{l}\text { The effect of monetary policy shocks on house prices } \\
\text { is amplified when houses serve as collateral to lower } \\
\text { borrowing costs according to a general equilibrium } \\
\text { model with frictions in credit markets. }\end{array}$ & UK & $1970-2001$ \\
\hline $\begin{array}{l}\text { Gupta, } \\
\text { Jurgilas, } \\
\text { and } \\
\text { Kabundi } \\
(2010)\end{array}$ & $\begin{array}{l}\text { The authors using a factor-augmented vector } \\
\text { autoregression find that monetary policy shock has a } \\
\text { negative impact on house price inflation. }\end{array}$ & South Africa & 1980-2006 \\
\hline $\begin{array}{l}\text { White } \\
\text { (2015) }\end{array}$ & $\begin{array}{l}\text { The author employs a Johansen cointegration approach } \\
\text { and reveals that money supply impacts house prices } \\
\text { permanently with the expected signs in the national } \\
\text { and regional level. In the regional level, however, we } \\
\text { may find significant variations in the results. }\end{array}$ & UK & 1983-2011 \\
\hline
\end{tabular}


Money, credit and house prices are influenced by many concomitant factors including lending standards, financial innovations, institutional differences (Muellbauer, 2015), capital inflows from the rest of the world (Sá \& Wieladek, 2015) due to the global savings glut (Bernanke, 2005) and by "loose" monetary policy (Gete, 2015). According to the theory, the interrelations between money/credit growth and house price inflation reveal through housing wealth, an optimal portfolio adjustment mechanism, search-for-yield behaviour, the so-called "risk-taking" channel of monetary transmission, collateral effects on credit demand and credit supply, Tobin's $q$ effects on investment and a lower discount factor as outlined in detail by Goodhart and Hoffman (2008) and European Central Bank [ECB] (2010, pp. 309-311).

\section{Data}

House prices are nominal residential property price indices. In order to increase the comparability of the data among countries they come from one source only, namely from the BIS Residential Property Price database. The time series on house prices were harmonised in line with the recommendations in the Handbook on residential property prices and an internationally agreed framework for classifying property price issues. The need for such adjustments were required as the series originate from data provided by various sources, including central banks, national statistical offices, research institutes, private companies and academic studies (see, Table 1A).

To maintain the comparability of credit data with house price data as much as possible, the measures of credit were extracted from the new Bank for International Settlements (BIS) database. These are credit to private non-financial sector (PNFS) from banks and credit to PNFS from all sectors. Credit to PNFS include the following borrowing sectors: non-financial corporations (both private and public-owned), households and non-profit institutions serving households. The credit data are compiled at market value on a non-consolidated basis. The combination of data from different methodological frameworks resulted in breaks in the series. Therefore, the BIS break-adjusted series are used. They were obtained by adjusting levels through standard statistical techniques described in Dembiermont, Drehmann, and Muksakunratana (2013).

The data used for the M3 and M2 monetary aggregates (M2 - alternate scenario) had to be taken from another source of data because monetary aggregates are not included in the BIS database. Therefore, they were extracted from the International Monetary Fund (IMF, International Financial Statistics database). Only if the time series of a required length were not available, the time series from the Federal Reserve Bank of St. Louis (FRED) were used instead (Table 2A). Data for the real GDP in national currency come from OECD (the expenditure approach) in volume estimates for the annual levels. The fact of using OECD data source for this purpose should not decrease the overall quality and comparability of the different time series used in this study. The OECD real GDP time series originate from highly relevant sources, namely from domestic statistical offices or central banks.

All the series are quarterly. They range from 1Q 1970 up to 4Q 2016 with few exceptions. The exceptions most frequently concern shorter M2 series in some countries and shorter series for the euro area. The input data are logarithmic growth rates of seasonally adjusted time series with the detection and correction for outliers with X-12 ARIMA. 


\section{Methodology}

The standard techniques for characterizing correlated behaviour in time or frequency are the (Fourier) cross-spectrum, cross-correlation, and coherence. Nevertheless, the frequency content of time series changes. It is particularly expected in case of money, credit and house prices. Therefore, the standard techniques are not appropriate for the historical analyses. In particular, the well-known Fourier transform provides no information on the development of the frequency content over time. In turn, the windowed Fourier transform results in not an adequate resolution for all the frequencies if a broad range of frequencies is considered.

In the wavelet analysis the problem is avoided due to an endogenously changing time window. The time series are decomposed into wavelets. Wavelet is a stretched version of a mother wavelet localized both in time and in frequency domains. A wavelet $\psi$ is a function that integrates to zero, has a unit energy (Bruzda, 2013) and a limited period of fluctuations (Fan \& Gençay, 2010). Therefore, the function meets the following conditions: $\int \psi(n) d n=0$ and $\int|\psi(n)|^{2} d n=1$. Wavelet transform is proposed in the study as instantaneous frequency estimator due to its ability to decompose complex information and patterns into elementary forms. The continuous wavelet transform (CWT) of a square-integrable signal $g$ is defined thus as:

$$
C W T_{g}(a, b)=\frac{1}{\sqrt{a}} \int_{\Re} g(t) \overline{\left(\frac{t-b}{a}\right)} d t,
$$

where $a>0$ is the scale parameter and $b \in \mathfrak{R}$ is the translation parameter. For the wavelet analyses, there were used ASToolbox (Aguiar-Conraria \& Soares, 2013) and the cross wavelet and wavelet coherence toolbox for MATLAB (Grinsted et al., 2004) as well as own modifications of the codes.

A complex Morlet wavelet (Grossmann \& Morlet, 1984) was chosen as a mother wavelet. The Morlet wavelet allows for the optimal time-frequency resolution with respect to the Heisenberg inequality. The amplitude and local phase can be examined with the formulae:

$$
\psi(t)=\frac{1}{\sigma^{1 / 2} \pi^{1 / 4}} e^{-\frac{t^{2}}{2 \sigma^{2}}} e^{i k_{0} t},
$$

where $\sigma>0$ and $k_{0}$ are constants. For the optimal balance, the parameters $\sigma=1$ and $k_{0}=6$ as suggested by Torrence and Compo (1998). In consequence, there is a direct relationship between the wavelet scale and the Fourier frequency (Aguiar-Conraria \& Soares, 2013).

The study uses wavelet coherency to measure the time synchronization between money (credit) growth and house price inflation. The wavelet coherency is defined as follows:

$$
K_{x y}^{2}(a, b)=\frac{\left|s\left\{X W T_{x y}(a, b)\right\}\right|}{s\left\{\left|C W T_{x}(a, b)\right|\right\} s\left\{\left|C W T_{y}(a, b)\right|\right\}},
$$

where $s$ denotes a smoothing operator in time and scale, $x$ and $y$ are two signals: $x, y \in L^{2}(\mathfrak{R})$ and XWT stands for the cross wavelet transform: $X W T_{x y}(a, b)=C W T_{x}(a, b) \overline{C W T_{y}(a, b)}$. 
The wavelet coherency analyses the co-movements of the two time series. It is the timefrequency domains correlation coefficient - similar to the conventional correlation analysis and to the dynamic conditional correlation analysis. With the XWT, the linkage between money/credit growth and house price inflation is assessed at different frequencies and moments in time.

The wavelet coherency takes values from zero (no co-movements) to one (the strongest correlation between the time series) - like for the traditional correlation coefficient. The wavelet coherency is marked with colours to facilitate the interpretation. Yellow colours correspond to a strong correlation, while blue colours stand for no or weak co-movements. Dark lines mark the statistically significant estimates of the wavelet coherency at the 0.1 level. All the tests of significance assumed constant $\mathrm{AR}(2)$ background spectra.

The black curved lines represent the so-called cone of influence (COI). Areas of high coherence occurring outside or overlapping COI should be interpreted with caution. They might be affected by zero padding, while the edge effects may distort the result. COI was introduced to visualize the set of wavelet coefficients influenced by the value of the signal at a specified position for wavelets completely localized in time (Mallat, 1999, p. 174).

I introduce the wavelet phase difference to analyse the causality between the time series in time and frequency. The wavelet phase difference or the wavelet phase spectrum is defined as:

$$
\phi_{x y}(a, b)=a \tan \frac{\mathfrak{I}\left\{X W T_{x y}(a, b)\right\}}{\mathfrak{R}\left\{X W T_{x y}(a, b)\right\}},
$$

where $\phi_{x y}(a, b) \in(-\pi, \pi)$ and the function "atan" is treated as the (2-argument) four-quadrant inverse tangent.

A phase difference of zero implies that the two time series move together. A phase difference of $\pi$ indicates that they move in the opposite direction. If $\left|\phi_{x y}(a, b)\right| \leq \frac{\pi}{2}$ the two signals are in phase (a positive instantaneous correlation). If $\left|\phi_{x y}(a, b)\right|>\frac{\pi}{2}$ there is an anti-phase relationship (a negative instantaneous correlation), analogous to a negative covariance. The wavelet phase difference is marked with arrows. Phase arrows pointing to the right side: in phase, left: anti-phase, perfectly up: money/credit growth is leading house price inflation by $\pi / 2$, perfectly down: house price inflation is leading money/credit growth by $\pi / 2$.

I use the wavelet gain coefficient to measure the amplification of amplitudes of the signal of house price inflation due to the changes in amplitudes of the signal of money (credit) growth. The coefficient should equal unity in case an expansion of money/credit growth by $1 \%$ would push up house prices by $1 \%$. The coefficient is defined as follows:

$$
G_{x y}(a, b)=\frac{\left|s\left\{X W T_{x y}(a, b)\right\}\right|}{s\left\{\left|C W T_{x y}(a, b)\right|^{2}\right\}} .
$$

The time variation of the average values of the gain coefficients was tested in the cycles of 2-8 and 8-16 years with their constancy tests generated according to VAR(2) models. 
The analysis is split into two subsamples: 1Q 1970 - 4Q 1983 (before the Great Moderation) and 1Q 1984 - 4Q 2016 (since the Great Moderation). The starting date of the Great Moderation was selected after McConnell and Perez-Quiros (2000) who found a structural decline in the volatility of real US GDP growth. The joined analysis could have violated the assumption of constant background spectra, because output volatility experienced a large decline in most of the industrialized countries since the mid-1980s. The first, period covers the effects of financial systems liberalisations in the 1970s and 1980s. Meanwhile, the literature falls short in applying the time and frequency domain methods to compare the linkage between money/credit and house prices before and since the beginning of the Great Moderation and during the Great Recession. The methodology employed in this article follows a recently modern strand of wavelet decomposition of a signal in the time-frequency domain (see, Kapounek \& Kučerová, 2018). The value added of such an approach is the use of a wide range of tools including the wavelet coherence, wavelet power spectra, the band-pass study of significance of power changes, phase differences and the wavelet gain coefficients using different monetary and credit variables, analyzing wavelet gain coefficients for different cycles and verifying the justification to carry out the analysis separately in sub-periods. In consequence, the results are robustified to different financial variables, real GDP changes, and specific sub-periods before and since the Great moderation.

The results on the interconnectedness of money/credit and house price inflation focus on those countries that adopted QE to an unconventional scale in order to provide a fresh assessment of this extraordinary monetary policy from the wavelet perspective. Moreover, the results are compared for all of the countries during normal times and house price booms. A boom is defined as a consecutive positive deviation of house prices from a smooth H-P trend (smoothing parameter $=100,000$ ) of more than $5 \%$ lasting at least 12 quarters.

\section{Empirical results}

The Figure 1a reveals that average M3 money growth (GDP corrected in Figure 1b) plotted against average house price inflation formed a line close to 45 degrees. The drawn lines that represent the linear regressions of money growth on house prices had the 43 and 46 degree angles, the latter value after the real GDP adjustment. For the 0.95 confidence interval, the mean angle was likely to be less than 40.5 degrees $(t$-test $=-4.96)$. After the real GDP adjustment, the hypothesis that the mean angle equaled to 45 degrees $(t=0.68)$ was not rejected, i.e.: a given change in the rate of change in the quantity of money induces an equal change in the rate of house price inflation.

Credit aggregates and house price inflation were also positively and strongly correlated, although the angle was few percentage points smaller (Figure 1c, d). For the 0.95 confidence interval, the mean angle was likely to be less than 38 degrees for both measures of credit (Figure 1c: $t$-test $=-8.11$; Figure $2 \mathrm{~d}$ : -8.87 ). Naturally, correlation does not imply causality. Therefore, the article explores the linkage with more advanced methods. 


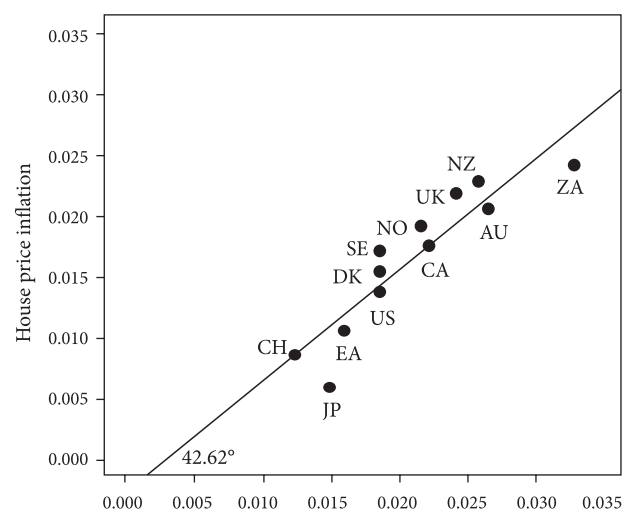

a) $\Delta \mathrm{M} 3$

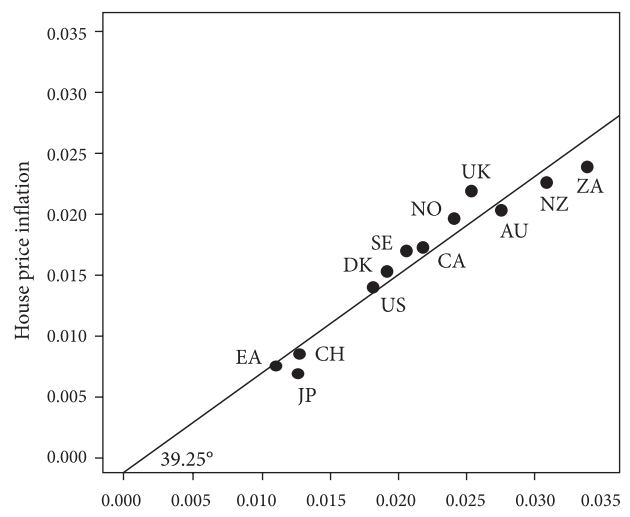

c) $\Delta$ bank credit

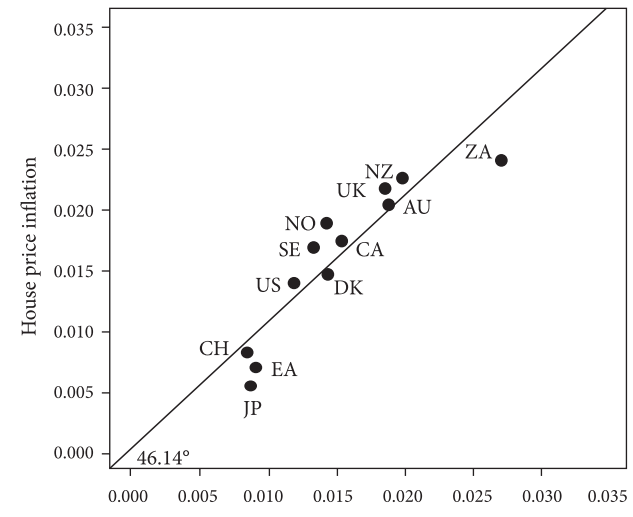

b) $\Delta \mathrm{M} 3-\Delta$ real GDP

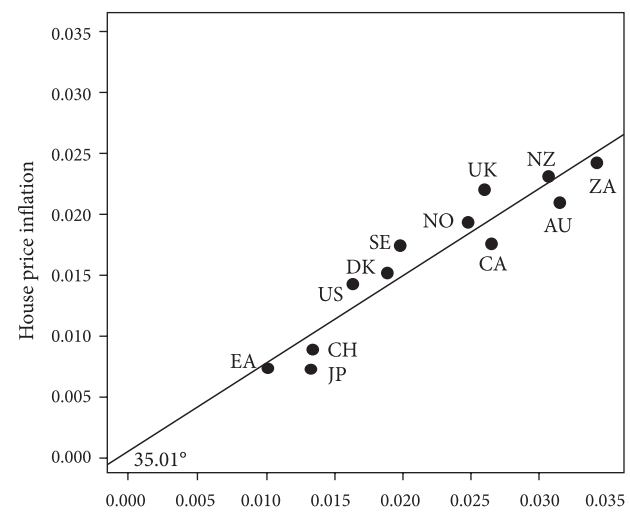

d) $\Delta$ credit from all sectors

Note: For the EA, plots a, c cover the period from 3Q 1980 to 4Q 2016, b from 2Q 1995 and d from 1Q 1999.

Figure 1. Average quarterly money/credit growth versus house price inflation from 1Q 1970 to 4Q 2016 (source: own work)

\subsection{Since 1970 until the beginning of the great moderation}

The results point to a strong, significant ${ }^{3}$, positive and often close to the one-for-one link between growth rate of money (M3: Figure 2, M2: not reported) or credit (Bank credit: Figure 3, Credit to PNFS from all sectors: not reported) and house price inflation before 1984 .

Only in Norway, Switzerland and Sweden, significant co-movements have not extended over the whole interpretable time span between house price inflation and at least one of the financial variables. However, even Norway and Switzerland had about a decade long time

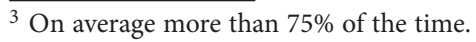


period (NO: 12 years, $\mathrm{CH}$ : 8 years) of significant co-movements in case of M3 adjusted for real GDP growth and credit to PNFS from all sectors, respectively.

Predominantly, financial variables and house prices co-moved in the same direction, although it was not always clear if financial variables or house prices were leading. Generally, if the co-movements were significant, the growth rate of money/credit was leading house price inflation in Australia, Japan, Sweden, New Zealand and South Africa (for at least one measure of money or credit). The opposite direction concerned the United States, Norway, Denmark and Canada. The typical business cycle gains were close to or above unity (on average more than 0.8 ). The notable exceptions were the United States and Australia where the gains for house prices with respect to M3 and credit were below one (not reported). Generally, house price inflation followed changes in money growth or the co-movements had a positive instantaneous correlation more than $93 \%$ of the time (for significant co-movements). The relevance of credit developments for house price inflation was inferior (analogous values ranged from 59\% to 70\%).
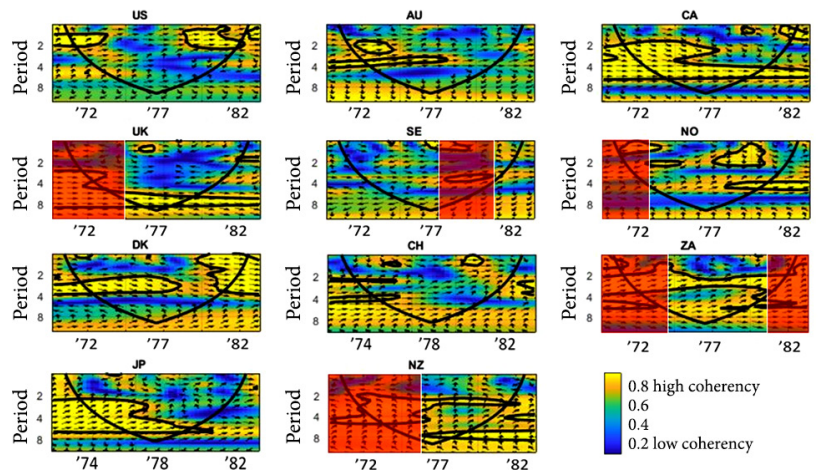

0.8 high coherency

0.6
0.4

0.2 low coherency

Note: The number of bootstrap samples: 500. Frequency unit is a year [left hand-side of all the plots]. Red-shaded areas represent the episodes of house price booms according to Table 1. Figure 2 for Japan and Switzerland start from 4Q 1971.

Figure 2. Wavelet coherency between M3 money growth and house price inflation from 1Q 1970 to 4Q 1983 source (own work)
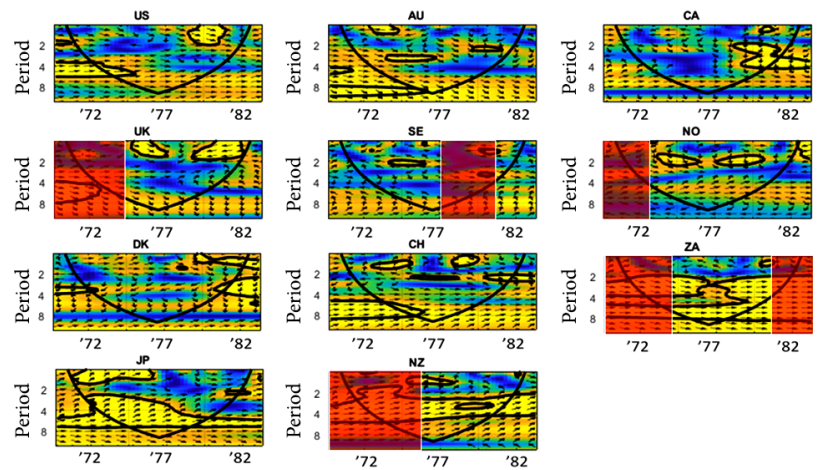

Note: See note to Figure 2.

Figure 3. Wavelet coherency between bank credit growth and house price inflation from 1Q 1970 to 4Q 1983 (source: own work) 
Separate analysis before and since the Great Moderation was generally supported by the band-pass study of significance of power changes and the wavelet power spectra. In line with expectations, the volatility in individual time series of money, credit and house prices was more homogenous within these subsamples than for the full time span (not reported).

\subsection{Since the great moderation until 2016}

As opposed to the pre-1984 period, significant co-movements between money growth and house price inflation typically did not extend over the whole interpretable period. The prevailing direction of the link has changed. House price inflation started to lead money and credit growth in most countries typically by 1-3.5 year ${ }^{4}$. The significant link concerned usually a typical business cycle frequency range while money/credit and house prices typically co-moved in the same direction (more than $90 \%$ of the time). Moreover, the estimates of gains for house prices with respect to M3 and credit were often very high $(>1)$ (Figures 6-7), but the effect was not always statistically significant. Notwithstanding this, the linkages and lead-lag effects between these two variables are generally time and frequency-varying as it is presented in Figures 4 and 5. The result of Bjørnland and Jacobsen (2010) was thus confirmed that the strength and timing of response of house prices to changes in monetary policy instruments and financial variables varies among the countries. The result suggests that different roles may be assigned to housing in the monetary policy setting across the countries investigated. The knowledge about the strength of responses of house prices to changes in financial variables in a given country is crucial for monetary policy authorities to react appropriately to the emerging financial imbalances.

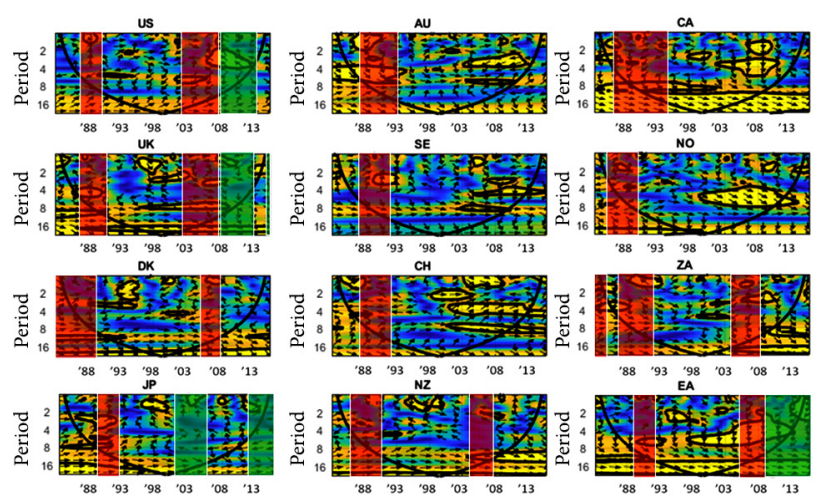

Note: Green-shaded areas represent the episodes of unconventional asset purchases/quantitative easing policies. See note to Figure 2.

Figure 4. Wavelet coherency between M3 money growth and house price inflation from 1Q 1984 to 4Q 2016 (source: own work)

\footnotetext{
4 The few exceptions when money growth was leading house price inflation after 1984 were: a) Sweden during a housing boom of 1988-1992, b) Switzerland for the post 2003 data, c) Denmark between 1990 and 1995, d) the United States from 2007 to 2013, e) Japan before and in the early 90 s.
} 


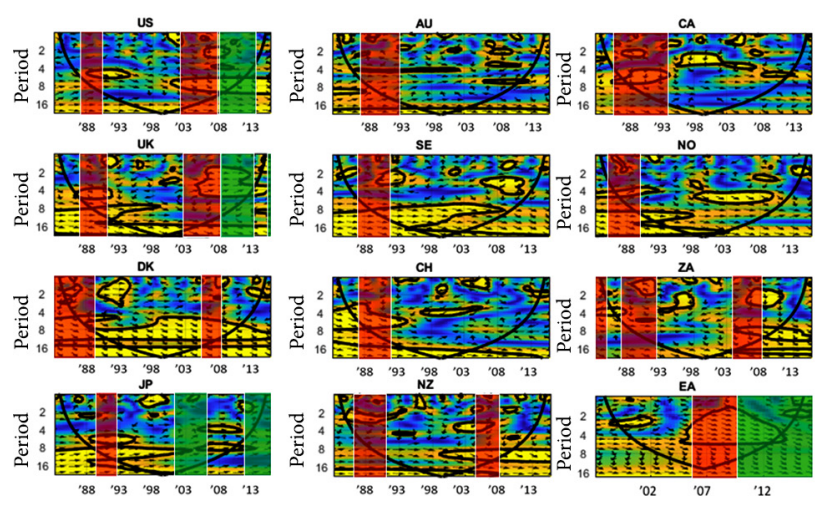

Note: See note to Figure 2. Figure 5 for the euro area starts from 1Q 1997.

Figure 5. Wavelet coherency between bank credit growth and house price inflation from 1Q 1970 to 4Q 1983 (source: own work)

Table 2. House price booms (1970-2016) (source: own work)

\begin{tabular}{|l|l|}
\hline Australia & 3Q $1988-$ 1Q 1993 \\
\hline Canada & 1Q 1988 - 4Q 1994 \\
\hline Denmark & 1Q 1984 - 3Q 1989; 3Q 2005 - 4Q 2008 \\
\hline Japan & 4Q 1989 - 3Q 1993 \\
\hline New Zealand & 1Q 1970 - 1Q 1976; 1Q 1987 - 1Q 1991; 1Q 2005 - 2Q 2008 \\
\hline Norway & 1Q 1970 - 2Q 1973; 4Q 1985 - 2Q 1990 \\
\hline South Africa & $\begin{array}{l}\text { 1Q 1970 - 3Q 1974; 1Q 1981 - 1Q 1986; 4Q 1987 - 4Q 1992; 4Q 2004 - } \\
\text { 4Q 2008 }\end{array}$ \\
\hline Sweden & 2Q 1977 - 4Q 1980; 3Q 1988 - 3Q 1992 \\
\hline Switzerland & 1Q 1988 - 2Q 1993 \\
\hline the United Kingdom & 1Q 1970 - 4Q 1974; 4Q 1987 - 1Q 1992; 2Q 2003 - 3Q 2008 \\
\hline the United States & 4Q 1987 - 4Q 1990; 4Q 2003 - 1Q 2008 \\
\hline Euro area* & 2Q 1990 - 2Q 1993; 3Q 2005 - 1Q 2009 \\
\hline
\end{tabular}

Note: A boom is defined as a consecutive positive deviation of house prices from a smooth $\mathrm{H}-\mathrm{P}$ trend (smoothing parameter $=100,000)$ of more than $5 \%$ lasting at least 12 quarters. ${ }^{*}$ Data for the EA from 1980 .

Moreover, significant co-movements between money/credit and house prices were predominantly not rejected around specific sub-periods of booming house prices ${ }^{5}$ (red-shaded areas in Figures 4-5, Tables 2, 3). The findings quite surprisingly contradict those of Del Negro and Otrok (2007), who using a VAR model found that the impact of monetary policy shocks on house prices was relatively small in the US during the 2001-2005 time period associated with the pre-Great Recession boom. The CWT results are, however, in line with

\footnotetext{
${ }^{5}$ Depending on the choice of a financial variable for $80 \%$ to $96 \%$ of all of the detected episodes of house price booms.
} 
Table 3. Co-movements and causality between financial variables and house price inflation during house price booms (1970 and 2016) (source: own work)

\begin{tabular}{|c|c|c|c|c|c|}
\hline CTR & House price boom & $\Delta \mathrm{M} 3$ & $\Delta \mathrm{M} 3$ mod.GDP & $\Delta$ Bank Credit & $\Delta$ Credit All Sec. \\
\hline $\mathrm{AU}$ & 3Q 1988 - 1Q 1993 & $-\backslash(\mathrm{b})$ & - $\downarrow(b)$ & $\boldsymbol{\longrightarrow} \rightarrow(\mathrm{b}, 1 !)$ & $\begin{array}{l}\theta>(b), \\
-(1 !)\end{array}$ \\
\hline $\mathrm{CA}$ & 1Q 1988 - 4Q 1994 & $\checkmark(\mathrm{b}, \mathrm{l})$ & $\longrightarrow(\mathrm{b}, \mathrm{l})$ & (b) & $\begin{array}{l}\theta>(b) \\
->(1 !)\end{array}$ \\
\hline \multirow{2}{*}{ DK } & 1Q 1984 - 3Q 1989 & $\rightarrow(1 !)$ & $\theta_{\boldsymbol{T}}(1 !)$ & $>(\mathrm{b} !, \mathrm{l} !)$ & $>(b !, 1 !)$ \\
\hline & 3Q $2005-4 Q 2008$ & $\backslash(1 !)$ & $\ominus \leftarrow(b), \bullet(1 !)$ & $>(b, 1)$ & $>(b, 1)$ \\
\hline $\mathrm{JP}$ & 4Q 1989 - 3Q 1993 & $\ominus \boldsymbol{\nabla}(\mathrm{b}) \bullet \rightarrow(\mathrm{l} !)$ & $\uparrow(b), \bigcirc \rightarrow(1 !)$ & $\rightarrow(b, 1)$ & $\boldsymbol{\top}(\mathrm{b}, 1 !)$ \\
\hline \multirow{3}{*}{$\mathrm{NZ}$} & 1Q $1970-1 Q 1976$ & $\bullet \uparrow(\mathrm{b})$ & $\theta_{k(b)}$ & $-\nabla(b)$ & $\longrightarrow(\mathrm{b})$ \\
\hline & 1Q 1987 - 1Q 1991 & 0 & $\theta \leftrightarrows(b)$ & $\rightarrow(b, 1 !)$ & $\rightarrow(1 !)$ \\
\hline & 1Q $2005-2 Q 2008$ & $\checkmark(\mathrm{b}, \mathrm{l})$ & 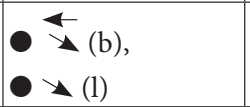 & 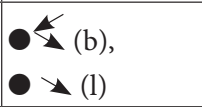 & $\begin{array}{l}0 \\
0 \\
0\end{array}$ \\
\hline \multirow[b]{2}{*}{ NO } & 1Q 1970 - 2Q 1973 & 0 & O & 0 & 0 \\
\hline & 4Q 1985 - 2Q 1990 & $\backslash(1 !)$ & ○ $(\mathrm{b}, \mathrm{l} !)$ & $\begin{array}{l}\boldsymbol{\nabla}(\mathrm{b}) \\
\boldsymbol{\lambda}(\mathrm{l})\end{array}$ & $\downarrow(1 !)$ \\
\hline \multirow{4}{*}{$\mathrm{ZA}$} & 1Q 1970 - 3Q 1974 & $-\rightarrow(b)$ & $\longrightarrow(\mathrm{b})$ & $\rightarrow(b)$ & $\rightarrow(b)$ \\
\hline & 1Q 1981 - 1Q 1986 & $\nabla^{\top}(b !)$ & $\hat{\forall}(\mathrm{b} !)$ & $\vec{\nabla}(\mathrm{b} !)$ & $\vec{\nabla}(b !)$ \\
\hline & 4Q 1987 - 4Q 1992 & 0 & $\nabla(b)$ & $\theta>(b)$ & 0 \\
\hline & 4Q $2004-4 Q 2008$ & $\ominus \downarrow$ (b), $\bullet \backslash(1 !)$ & $\Theta<(b), \bigcirc \backslash(1 !)$ & $>(b, 1 !)$ & $\backslash(\mathrm{b}, 1 !)$ \\
\hline \multirow{2}{*}{ SW } & 2Q $1977-4 Q 1980$ & $\nabla(b)$ & $\sim(\mathrm{b} !)$ & 0 & 0 \\
\hline & 3Q 1988 - 3Q 1992 & $\Theta^{\uparrow}(\mathrm{b})$ & - $\uparrow_{(b)}$ & $\rightarrow(b, 1 !)$ & $\rightarrow(b, 1 !)$ \\
\hline $\mathrm{CH}$ & 1Q $1988-2$ Q 1993 & 0 & $\theta_{k(b)}$ & $>(b, 1 !)$ & $>(b, 1 !)$ \\
\hline \multirow{3}{*}{ UK } & 1Q 1970 - 4Q 1974 & $\rightarrow(b !)$ & $>(b !)$ & $\theta>(b !)$ & $0 \backslash(\mathrm{b})$ \\
\hline & 4Q 1987 - 1Q 1992 & $\bullet \downarrow(\mathrm{b}), \bullet \searrow(1 !)$ & $\mathscr{O}<\mathrm{(b)}$ & $>(\mathrm{b}, \mathrm{l} !)$ & $>(b, 1 !)$ \\
\hline & 2Q $2003-3 Q 2008$ & $\backslash(\mathrm{b}, \mathrm{l})$ & $\begin{array}{l}\boldsymbol{O}_{\mathrm{k}}(\mathrm{b}), \\
\boldsymbol{\nabla}(\mathrm{l})\end{array}$ & 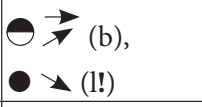 & $\backslash(1 !)$ \\
\hline \multirow{2}{*}{ US } & 4Q 1987 - 4Q 1990 & 0 & $\boldsymbol{O} \sim(\mathrm{b})$ & $\theta>(b)$ & $\Theta \backslash(b), \bigcirc \backslash(l !)$ \\
\hline & 4Q $2003-1 Q 2008$ & $>(\mathrm{b})$ & $>(b)$ & $\Delta(\mathrm{b})$ & $\backslash(b, 1)$ \\
\hline \multirow{2}{*}{ EA } & 2Q 1990 - 2Q 1993 & $\boldsymbol{\downarrow}(\mathrm{b}), \mathbf{O} \rightarrow(\mathrm{l} !)$ & NA & NA & NA \\
\hline & 3Q $2005-1 Q 2009$ & $\downarrow$ \(b), $\longrightarrow(1 !)$ & $\bullet<(b), \bigcirc(\mathrm{l})$ & $-\backslash(b)$ & $\backslash(b)$ \\
\hline
\end{tabular}

Note: Periods of house price booms are based on Table 1. Co-movements and causality are based on Figures 2-5. Full black circle marks significant co-movements between growth of a financial variable and house price inflation over the entire boom. Half-white circle marks significant co-movements between growth of a financial variable and house price inflation over the majority of a boom period. White circle marks no significant co-movements during a boom or significant co-movements lasted shorter than half of a boom period. Areas outside the cone of influence must be interpreted with caution. The exclamation mark (!) is used if majority of significant co-movements during a boom are outside of a cone of influence. The exclamation mark might be associated with a typical business cycle frequency range $(b=$ business cycle) $[2-8$ years cycle], but mostly often with longer run developments $(1=$ longer run developments) [8+ years cycle]. Arrows mark causality: right: positive co-movements, left: anti-phase, up: growth rate of the financial variable is leading house price inflation by $\pi / 2$, down: house price inflation is leading growth rate of the financial variable by $\pi / 2$. 
an international study of Goodhart and Hoffman (2008), who also found considerable interdependence between money/credit and house prices and the effect of rising correlations when house prices are booming. The discrepant results of Del Negro and Otrok (2007) may not stem only from different methodologies used but also from a trial to distinguish whether the monetary/credit growth before the Great Recession was the result of monetary policy setting. It is, however, not investigated in this article. Notwithstanding this, the CWT findings have profound consequences for the monetary policy. They suggest that central banks should carefully monitor house prices in order to react to the emerging financial imbalances by increasing restrictions on money/lending if they find it necessary to mitigate the adverse longer-run consequences of a bubble's burst. The viability of such restrictions stems from the significant and strong co-movements between money/credit and house prices for a business cycle frequency during booming episodes.

Interestingly, the impact of money and credit developments on house prices was strikingly diversified during QE (green-shaded areas) in the US, EA, JP and the UK. Finocchiaro and Von Heideken (2013) found that house prices played a separate role in the reaction functions of Fed, the Bank of England and the Bank of Japan according to the dynamic stochastic general equilibrium model embedded with a monetary rule with a direct response to house prices. The wavelet results, though mixed, could be interpreted in line with the study of Finocchiaro and Von Heideken (2013) for the US and the UK, but not for Japan. In the US and UK, growth of respectively broad money and bank credit was leading house price inflation after 2007. The uncommon for the post-1984 time period causality could mean that Fed and the BoE indeed assigned importance to property prices and stimulated them through successful easing of monetary and credit conditions after the outbreak of the Great Recession. As opposed to it, the BoJ and the ECB either have not assigned separate roles to house prices in their reaction functions or were not capable to significantly influence them by extending money/credit through unconventional asset purchases and other activities in the horizon of 2 to 8 years.

Since there is clearly no consensus on the effects of money and credit on asset prices during $\mathrm{QE}$, in the following part the article will focus on the period of unconventional monetary policy. In the US, before the outbreak of the Great Recession money and credit growth followed inflation of house prices. Rising value of mortgages through the wealth effect (Campbell \& Cocco, 2007), an increased value of the collateral (Muellbauer, 2007), the renters' saving effect (Sheiner, 1995) or low interest rates could have induced more lending (Figures 4-5). The causality reversed since 2007 for M3 (Figure 4), but not for credit. The date corresponds to an introduction of Large Scale Asset Purchases (LSAP) in 2008 that were continued until October 2014. Since their beginning, money growth started to lead changes in house prices for the 2-4 years cycle. The new causality going from money to house prices since 2007 could be interpreted as in line with the Fed's official statements. Purchases of housingrelated obligations and mortgage-backed securities were to increase the availability of credit for the purchase of houses and to support housing markets in general. ${ }^{6}$ Finally, money gains were rising above unity in the US after 1990s which confirms the growing interdependence between money and house prices.

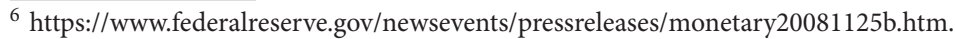


The correlation between money growth and house price inflation during LSAP was, however, negative. It is against the expected mechanism of QE to raise the price of higher-yielding assets. The negative correlation could be attributed to a) a downward pressure on house prices due to the large amount of bad credits in an environment of high uncertainty; b) risk aversion that expanded narrow money and to some extent broader aggregates; c) inflows of dollars held abroad into the US banking system due to the unlimited guarantee introduced by the Federal Deposit Insurance Corporation in 2008. Therefore, the evidence on the role of money growth in stimulating house price inflation as a result of QE is mixed in the US and requires further investigation.

In the euro area, significant co-movements between money growth and house price inflation covered the whole available time span for the $2-8$ and $12+$ years cycle. Money growth followed inflation of house prices for a typical business cycle. For the longer run develop-
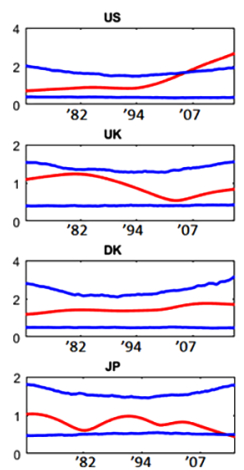
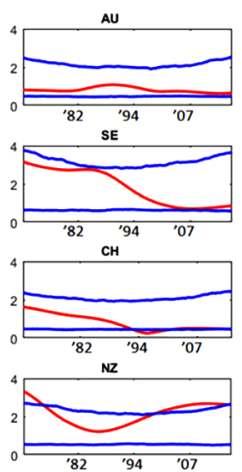

CA

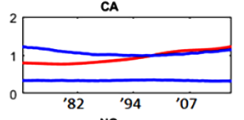

NO
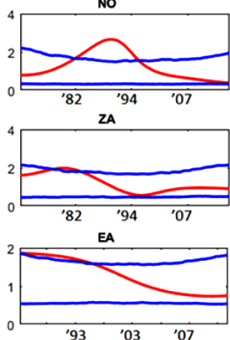

Note: The number of bootstrap samples: 1,000. The plots for Japan and Switzerland start from 4Q 1971. The plot for the euro area starts from 1Q 1980.

Figure 6. Estimates of the wavelet gain coefficients for house prices with respect to M3 - mean values in the interval of 8-16 years and their constancy tests in 1970-2016 (source: own work)
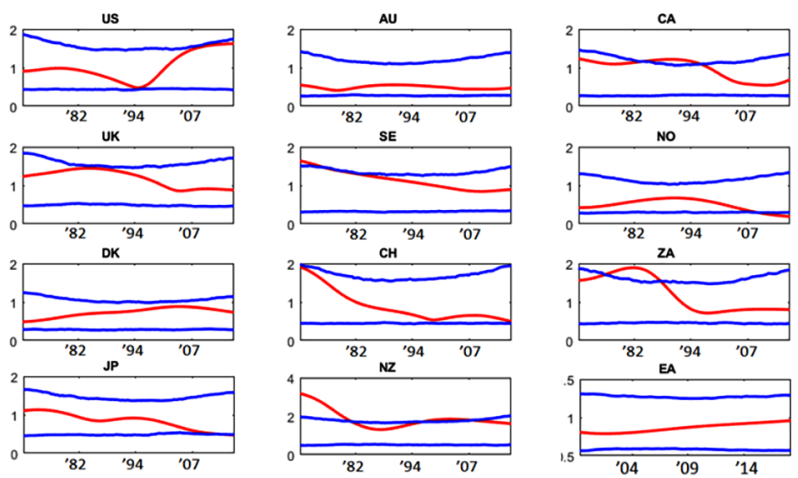

Note: The number of bootstrap samples: 1,000. The plot for the euro area starts from 3Q 1997.

Figure 7. Estimates of the wavelet gain coefficients for house prices with respect to bank credit mean values in the interval of 8-16 years and their constancy tests in 1970-2016 (source: own work) 
ments, money growth still followed changes in house prices, but the positive relation was moving towards an instantaneous one (most clearly at Figure 4). The results have a twofold, EA-specific interpretation. First, QE in EA has not managed to reverse the causality so that it would run from money/credit to house prices for the horizon of 2-8 years. The results complement other empirical studies which suggest that ECB's unconventional policies concerned predominantly interest rates and not lending (Creel, Hubert, \& Viennot, 2016; Beckworth, 2017).

Therefore, the CWT results provide further evidence to the study of Ahmad and Brown (2016) that ECB assigned much higher importance to its price-stability mandate than to the related sovereign debt crisis. This seems to be surprising, especially when taking into account the existence of a separate monetary pillar, which was created to monitor monetary dynamics. Ultimately, the macroeconomics outcomes in the euro area were far less favourable than in the US and in the UK (see, Weale \& Wieladek, 2016). The monetary policy of the ECB is the more surprising as the second EA-specific finding show that there exists a significant, positive, long run and close to an in-phase link between growth of M3 and house price inflation accompanied by estimates of the money gains with respect to house price inflation close to or above unity ${ }^{7}$ (Figure 6). The finding is thus a new wavelet argument for the ECB's two pillar monetary policy strategy. The CWT evidence implies that the dynamics of M3 exhibit longer run co-movements with house price inflation. Thus, the study contributes to the unresolved discussion on the validity of the ECB's monetary policy strategy between their proponents who attribute a special role to money (Barthélemy, Clerc, \& Marx, 2011), and opponents who point to the fragility of the European Monetary System (De Grauwe \& Ji, 2014).

In Japan, CWT identified positive and significant co-movements between monetary developments and house price inflation before 90s and in the early 90s. It was a bubble period that ended with an abrupt burst. When the bubble grew, money growth was leading booming house price inflation. It might be interpreted as a wavelet confirmation that Japanese monetary policy was overly expansionary and helped to fuel the bubble. The burst has driven Japan into large and long economic stagnation - the "Lost 20 Years". Since then, the significant link between monetary variables and house price inflation vanished. Money growth stagnated and the inability of the BoJ to maintain its growth was perceived by some as a reason for the economic stagnation and deflation (Canova \& Menz, 2010).

Despite the evidence that the first round of Japanese QE between 2001 and 2006 had a stimulating effect on investment and production (Honda, 2014), the wavelet link between monetary developments and house price inflation remained insignificant for the 2-8 years cycle (Figure 4). On the one hand, it could reflect the unsuccessful inflationary attempts of early QE. According to the study of Michaelis and Watzka (2017), unconventional measures failed to rise the consumer inflation before the "Abenomics" era of more expansionary policy. On the other hand, the CWT results showed that since 2007 money growth and house price inflation were either anti-phase or the link was insignificant. It might be interpreted as the BoJ's still ineffective stimulation of inflation - at least on the housing market and through

\footnotetext{
${ }^{7}$ It might be noted that the value close to unity of the estimates of the money gains with respect to consumer price inflation is expected by the quantity theory of money.
} 
money creation. The effectiveness in stimulating house prices by extending credit was only slightly more favourable than in case of monetary developments ${ }^{8}$.

In the UK, developments in bank credit were leading house price inflation for the 4 year cycles. On the other hand, credit from all sectors lagged house price inflation, while the link between money growth and house price inflation was either insignificant or negative after the real GDP adjustment. The results correspond with the mixed evidence on the QE's macroeconomic impact. While Joyce and Tong (2012) found significant and persistent impact of QE on gilt yields, lower interest rates have not translated into any apparent effect on the UK economy according to the study of Lyonnet and Werner (2012).

In sum, the diversified patterns in the co-movements between money/credit and house price inflation during QE coincided with macroeconomic performance. In the US and UK, the macroeconomic impact of QE was found by many researchers more favourable than in the euro area and Japan. This suggests relevant implications for monetary policy and for its evaluation. On the one hand, a more expansionary monetary policy during the Great Recession in the US and UK has brought more favourable macroeconomic results. On the other hand, however, the discovered significant longer run interdependencies between money/ credit and house prices during housing booms in all of the sample countries and during aggressive QE call for the right timing of the exit strategies from QE. The CWT results contribute, therefore, to the recently important issue associated with abandoning the expansionary monetary policy after the Great Recession (see, Berentsen, Kraenzlin, \& Müller, 2018).

The general results are robust to a change of money definition to the M2 (available upon request). The difference appears for the M2 after adjustment for the real GDP growth. For significant co-movements, growth of M2 and house price inflation were most frequently anti-phase in the 2-8 years cycle. The relation was in-phase for the longer run developments. The general results remained unchanged for the credit to PNFS from all sectors and when adjusting M3 and M2 monetary growth for the real GDP growth. They are available upon request together with the plots which represent the time variation of the average values of the gain coefficients for the $2-8$ years cycle.

\section{Conclusions}

This article studies the historical link between money/credit growth and house price inflation for the twelve industrialized countries through the lens of a novel application of a continuous wavelet analysis. The methodology allows to capture the time-varying features and to disentangle the short to the long-run effects so that economic analysts with different goal horizons could account for them to adjust their decisions more effectively.

The article contributes to the literature as it analyses the interconnectedness between money/credit and house price inflation using a long-term dataset when compared with similar studies. Moreover, the current literature is missing many benefits of using CWT to analyse the co-movements and lead-lag pattern across time and frequency. Most of the studies

\footnotetext{
8 The results show diminishing significance of the relationship between credit and house prices since around 2000. Moreover, the estimates of credit gains with respect to house prices have been falling below unity since around the mid-1990s.
} 
analyse the impact between money/credit and house prices only in one direction or without the possibility to distinguish that the relationship changes during normal times and during financial distress and across time horizons. Instead, the morale of the story told in this article is that the correlations between money/credit growth and house price inflation rise during the episodes of booming house prices in all of the sample countries for the longer run developments. The co-movements of financial variables and house prices around booming episodes suggest that a bubble can be stopped by increasing restrictions on lending. It could close the channels through which house prices, money and credit interact at the business cycle frequency. A viability of such a policy was argued, for example, by Gerdesmeier et al. (2010) based on a pooled probit-type approach. Wavelets confirmed, however, that a difficulty with "leaning against the wind" is associated with the evidenced diversity of the impact of money/credit on house prices between countries and for different time horizons. The knowledge about the strength of responses of house prices to changes in financial variables in a given country is important for monetary policy authorities to react appropriately to the emerging financial imbalances. Therefore, central banks should carefully monitor house prices in case they find it appropriate to mitigate the adverse longer-run consequences of a burst of an asset price bubble.

Moreover, in many pre-Great Recession papers it was argued that money and credit provide no useful information or that money is irrelevant. Instead, CWT shows that the dynamics of M3 exhibit longer run significant co-movements with house price inflation in the euro area both during normal times and booming house prices. Therefore, the study contributes to the unresolved discussion on the validity of the ECB's two-pillar monetary policy strategy. The CWT results deliver a new wavelet argument for a separate monetary pillar as M3 in the euro area may convey useful information about future inflation dynamics in the housing sector.

Wavelets delivered also fresh results on the behaviour of money and credit during quantitative easing. In the US and the UK, growth of respectively broad money and bank credit was leading house price inflation for the 2-8 years cycle. In contrast to this, the Bank of Japan and the European Central Bank either did not assign a separate role to house prices in their reaction functions or the two central banks were not capable to significantly increase house prices by extending money/credit during the business cycle. The diversified patterns in the co-movements between money/credit and house price inflation during QE coincided with macroeconomic performance. In the US and UK, the macroeconomic impact of QE was found by many researchers more favourable than in the euro area and Japan. This suggests relevant implications for monetary policy and for its evaluation. On the one hand, a more expansionary monetary policy during the Great Recession in the US and UK has brought more beneficial macroeconomic results. On the other hand, the discovered significant longer run interdependencies between money/credit and house prices during housing booms and during aggressive $\mathrm{QE}$ call for the right timing of the exit strategies from QE. The CWT results contribute, therefore, to the recently important issue associated with the plea to abandon the expansionary monetary policy after the Great Recession (see, Berentsen et al., 2018). In other words, the paper complements the strand of the literature which calls for the right timing of the exit strategies from quantitative easing. Additionally, the wavelet analysis largely sup- 
ports the need to consider different operational horizons when assessing the linkage between money and credit, which may have relevant implications for macroprudential policy.

The applications of wavelets in economics receive recently a growing attention. By using wavelets, the article sheds a new light on the co-movements and causality between selected financial variables and house price inflation across time and frequency. Nevertheless, the limitation of the study relies on the fact that the results were not backed by structural estimation. Therefore, an interesting future contribution would be to verify the interdependencies discovered by CWT with a good model of money, credit and housing sector. In particular, an interesting future contribution could be to combine money, credit, house prices and in general the financial sector into a unified structural macroeconomic model (see, Gu, Mattesini, \& Wright, 2016). Finally, a further study should verify to what degree money and credit impact economic volatility in the short and long run (see, Hedlund, 2018).

\section{Acknowledgements}

I thank professor Joanna Bruzda from Nicolaus Copernicus University in Toruń (Poland) for all the helpful comments and remarks.

\section{Funding}

This work was supported by the National Science Centre, Poland under Grant [2017/26/D/ HS4/00116] titled: "Money, Credit and House Prices from the Wavelet Perspective".

\section{Disclosure statement}

I declare that I do not have any competing financial, professional, or personal interests from other parties.

\section{References}

Adalid, R., \& Detken, C. (2007). Liquidity shocks and asset price boom/bust cycles (ECB Working Paper No. 732). Retrieved from http://conference.iza.org/conference_files/pada2009/detken_c5129.pdf

Aguiar-Conraria, L., \& Soares, M. J. (2013). The continuous wavelet transform: moving beyond uni- and bivariate analysis. Journal of Economic Surveys, 28(2), 344-375. https://doi.org/10.1111/joes.12012

Ahmad, A. H., \& Brown, S. (2016). Re-examining the ECB's two-pillar monetary policy strategy: are there any deviations during and the pre-financial crisis periods?. Empirica, 44(3), 585-607. https://doi.org/10.1007/s10663-016-9339-1

Anundsen, A. K., \& Jansen, E. S. (2013). Self-reinforcing effects between housing prices and credit. Journal of Housing Economics, 22(3), 192-212. https://doi.org/10.1016/j.jhe.2013.07.001

Aoki, K., Proudman, J., \& Vlieghe, G. (2004). House prices, consumption, and monetary policy: a financial accelerator approach. Journal of Financial Intermediation, 13(4), 414-435. https://doi.org/10.1016/j.jfi.2004.06.003

Baharumshah, A., \& Soon, S. (2015). Demand for broad money in Singapore: does wealth matter?. Journal of Economics \& Finance, 39(3), 557-573. https://doi.org/10.1007/s12197-013-9267-x 
Barthélemy, J., Clerc, L., \& Marx, M. (2011). A two-pillar DSGE monetary policy model for the euro area. Economic Modelling, 28(3), 1303-1316. https://doi.org/10.1016/j.econmod.2011.01.010

Beckworth, D. (2017). The monetary policy origins of the eurozone crisis. International Finance, 20(2), 114-134. https://doi.org/10.1111/infi.12110

Belke, A., Orth, W., \& Setzer, R. (2008). Sowing the seeds for the subprime crisis: does global liquidity matter for housing and other asset prices?. International Economics \& Economic Policy, 5(4), 403424. https://doi.org/10.1007/s10368-008-0123-y

Berentsen, A., Kraenzlin, S., \& Müller, B. (2018). Exit strategies for monetary policy. Journal of Monetary Economics, 99, 20-40. https://doi.org/10.1016/j.jmoneco.2018.05.002

Bernanke, B. (2005). The global saving glut and the US current account deficit (No. 77). Board of Governors of the Federal Reserve System (US). Retrieved from https://www.federalreserve.gov/ boarddocs/speeches/2005/200503 102/

Bernanke, B. S., Gertler, M., \& Gilchrist, S. (1999). Chapter 21 The financial accelerator in a quantitative business cycle framework. In Handbook of Macroeconomics (pp. 1341-1393). Elsevier. https://doi.org/10.1016/s1574-0048(99)10034-x

Bjørnland, H. C., \& Jacobsen, D. H. (2010). The role of house prices in the monetary policy transmission mechanism in small open economies. Journal of Financial Stability, 6(4), 218-229. https://doi.org/10.1016/j.jfs.2010.02.001

Bordo, M. D., \& Haubrich, J. G. (2010). Credit crises, money and contractions: an historical view. Journal of Monetary Economics, 57(1), 1-18. https://doi.org/10.1016/j.jmoneco.2009.10.015

Borio, C. \& Lowe, P. (2004). Securing sustainable price stability: should credit come back from the wilderness? (BIS Working Paper No. 157). Retrieved from https://www.bis.org/publ/work157.htm

Bruzda, J. (2013). Wavelet analysis in economics applications, Toruń: Nicolaus Copernicus University Press.

Bruzda, J. (2017). Real and complex wavelets in asset classification: an application to the US stock market. Finance Research Letters, 21, 115-125. https://doi.org/10.1016/j.frl.2017.02.004

Campbell, J. Y., \& Cocco, J. F. (2007). How do house prices affect consumption? Evidence from micro data. Journal of Monetary Economics, 54(3), 591-621. https://doi.org/10.1016/j.jmoneco.2005.10.016

Canova, F., \& Menz, T. (2010). Japan's lost decade: does money have a role?. Journal of the Japanese \& International Economies, 24(2), 178-195. https://doi.org/10.1016/j.jjie.2009.12.001

Cesa-Bianchi, A., Cespedes, L. F., \& Rebucci, A. (2015). Global liquidity, house prices, and the macroeconomy: evidence from advanced and emerging economies. Journal of Money, Credit and Banking, 47(S1), 301-335. https://doi.org/10.1111/jmcb.12204

Chen, M.-C., Chang, C.-O., Yang, C.-Y., \& Hsieh, B.-M. (2012). Investment demand and housing prices in an emerging economy. Journal of Real Estate Research, 34(3), 345-373.

Creel, J., Hubert, P., \& Viennot, M. (2016). The effect of ECB monetary policies on interest rates and volumes. Applied Economics, 48(47), 4477-4501. https://doi.org/10.1080/00036846.2016.1158923

De Grauwe, P., \& Ji, Y. (2014). The fragility of two monetary regimes: the European Monetary System and the Eurozone. International Journal of Finance \& Economics, 20(1), 1-15. https://doi.org/10.1002/ijfe.1500

Del Negro, M., \& Otrok, C. (2007). 99 Luftballons: Monetary policy and the house price boom across U.S. states. Journal of Monetary Economics, 54(7), 1962-1985. https://doi.org/10.1016/j.jmoneco.2006.11.003

Dembiermont, C., Drehmann, M., \& Muksakunratana, S. (2013). How much does the private sector really borrow? A new database for total credit to the private nonfinancial sector, BIS Quarterly Review, March, 65-81. Retrieved from https://www.bis.org/publ/qtrpdf/r_qt1303h.htm 
Duca, J. V., Muellbauer, J., \& Murphy, A. (2011). House prices and credit constraints: making sense of the US experience. The Economic Journal, 121(552), 533-551.

https://doi.org/10.1111/j.1468-0297.2011.02424.x

Dursun-de Neef, H. Ö. (2018). The transmission of bank liquidity shocks: evidence from house prices. Review of Finance, rfy001. https://doi.org/10.1093/rof/rfy001

Engle, R. (2002). Dynamic conditional correlation. Journal of Business \& Economic Statistics, 20(3), 339-350. https://doi.org/10.1198/073500102288618487

Ernst, E., \& Saliba, F. (2018). Are house prices responsible for unemployment persistence? Open Economies Review, 29(4), 795-833. https://doi.org/10.1007/s11079-018-9494-z

European Central Bank. (2010). Enhancing monetary analysis, Frankfurt: European Central Bank.

Fairchild, J., Ma, J., \& Wu, S. (2015). Understanding housing market volatility. Journal of Money, Credit and Banking, 47(7), 1309-1337. https://doi.org/10.1111/jmcb.12246

Fan, Y., \& Gençay, R. (2010). Unit root tests with wavelets. Econometric Theory, 26(05), 1305-1331. https://doi.org/10.1017/s0266466609990594

Ferrero, A. (2015). House price booms, current account deficits, and low interest rates. Journal of Money, Credit and Banking, 47(S1), 261-293. https://doi.org/10.1111/jmcb.12202

Finocchiaro, D., \& Von Heideken, V. Q. (2013). Do central banks react to house prices?. Journal of Money, Credit and Banking, 45(8), 1659-1683. https://doi.org/10.1111/jmcb.12065

Flor, M. A., \& Klarl, T. (2017). On the cyclicity of regional house prices: new evidence for U.S. metropolitan statistical areas. Journal of Economic Dynamics \& Control, 77, 134-156. https://doi.org/10.1016/j.jedc.2017.02.001

Gerdesmeier, D., Reimers, H., \& Roffia, B. (2010). Asset price misalignments and the role of money and credit. International Finance, 13(3), 377-407. https://doi.org/10.1111/j.1468-2362.2010.01272.x

Gete, P. (2015). Discussion of Sá and Wieladek. Journal of Money, Credit and Banking, 47(S1), 257-260. https://doi.org/10.1111/jmcb.12201

Goodhart, C., \& Hofmann, B. (2008). House prices, money, credit, and the macroeconomy. Oxford Review of Economic Policy, 24(1), 180-205. https://doi.org/10.1093/oxrep/grn009

Grinsted, A. J., Moore, C., \& Jevrejeva, S. (2004). Application of the cross wavelet transform and wavelet coherence to geophysical time series.582

Nonlinear Processes in Geophysics, 11, 561-566. https://doi.org/10.5194/npg-11-561-2004

Grossmann, A., \& Morlet, J. (1984). Decomposition of Hardy functions into square integrable wavelets of constant shape. SIAM Journal on Mathematical Analysis, 15(4), 723-736. https://doi.org/10.1137/0515056

Gu, C., Mattesini, F., \& Wright, R. (2016). Money and credit redux. Econometrica, 84(1), 1-32. https://doi.org/10.3982/ecta12798

Gunn, C. M. (2018). Overaccumulation, interest, and prices. Journal of Money, Credit and Banking, 50(2-3), 479-511. https://doi.org/10.1111/jmcb.12468

Gupta, R., Jurgilas, M., \& Kabundi, A. (2010). The effect of monetary policy on real house price growth in South Africa: a factor-augmented vector autoregression (FAVAR) approach. Economic Modelling, 27(1), 315-323. https://doi.org/10.1016/j.econmod.2009.09.011

Hedlund, A. (2018). Credit constraints, house prices, and the impact of life cycle dynamics. Economics Letters, 171, 202-207. https://doi.org/10.1016/j.econlet.2018.07.028

Hkiri, B., Hammoudeh, S., Aloui, C., \& Shahbaz, M. (2018). The interconnections between U.S. financial CDS spreads and control variables: new evidence using partial and multivariate wavelet coherences. International Review of Economics \& Finance, 57, 237-257. 
https://doi.org/10.1016/j.iref.2018.01.011

Honda, Y. (2014). The effectiveness of nontraditional monetary policy: the case of Japan. Japanese Economic Review, 65(1), 1-23. https://doi.org/10.1111/jere.12036

Jin, Y., \& Zeng, Z. (2004). Residential investment and house prices in a multi-sector monetary business cycle model. Journal of Housing Economics, 13(4), 268-286. https://doi.org/10.1016/j.jhe.2004.08.001

Jordà, Ò., Schularick, M., \& Taylor, A. M. (2015). Sovereigns versus banks: credit, crises, and consequences. Journal of the European Economic Association, 14(1), 45-79. https://doi.org/10.1111/jeea.12144

Joyce, M. A. S., \& Tong, M. (2012). QE and the gilt market: a disaggregated analysis. The Economic Journal, 122(564), F348-F384. https://doi.org/10.1111/j.1468-0297.2012.02552.x

Kapounek, S., \& Kučerová, Z. (2018). Historical decoupling in the EU: evidence from time-frequency analysis. International Review of Economics \& Finance, 60, 265-280. https://doi.org/10.1016/j.iref.2018.10.018

Kelly, R., McCann, F., \& O’Toole, C. (2018). Credit conditions, macroprudential policy and house prices. Journal of Housing Economics, 41, 153-167. https://doi.org/10.1016/j.jhe.2018.05.005

Leamer, E. E. (2015). Housing really is the business cycle: what survives the lessons of 2008-09?. Journal of Money, Credit and Banking, 47(S1), 43-50. https://doi.org/10.1111/jmcb.12189

Lyonnet, V., \& Werner, R. (2012). Lessons from the Bank of England on 'quantitative easing' and other 'unconventional' monetary policies. International Review of Financial Analysis, 25, 94-105. https://doi.org/10.1016/j.irfa.2012.08.001

Mallat, S. (1999). A wavelet tour of signal processing. London: Academic Press.

McConnell, M. M., \& Perez-Quiros, G. (2000). Output fluctuations in the United States: what has changed since the early 1980's? American Economic Review, 90(5), 1464-1476. https://doi.org/10.1257/aer.90.5.1464

Michaelis, H., \& Watzka, S. (2017). Are there differences in the effectiveness of quantitative easing at the zero-lower-bound in Japan over time?. Journal of International Money and Finance, 70, 204-233. https://doi.org/10.1016/j.jimonfin.2016.08.008

Muellbauer, J. (2007). Housing, credit and consumer expenditure. Paper presented at the 2007 Jackson Hole Symposium of the Federal Reserve Bank of Kansas, 31 August - 1 September 2007. Retrieved from https://www.kansascityfed.org/publicat/sympos/2007/pdf/muellbauer_0415.pdf

Muellbauer, J. (2015). Housing and the macroeconomy: inflation and the financial accelerator. Journal of Money, Credit and Banking, 47(S1), 51-58. https://doi.org/10.1111/jmcb.12190

Osińska, M., Kufel, T., Błażejowski, M., \& Kufel, P. (2018). Modeling mechanism of economic growth using threshold autoregression models. Empirical Economics, 1-50.

https://doi.org/10.1007/s00181-018-1560-2

Pintér, G. (2018). House prices and job losses. The Economic Journal, 129(618), 991-1013. https://doi.org/10.1111/ecoj.12613

Prieto, E., Eickmeier, S., \& Marcellino, M. (2016). Time variation in macro-financial linkages. Journal of Applied Econometrics, 31(7), 1215-1233. https://doi.org/10.1002/jae.2499

Ramcharan, R., \& Crowe, C. (2013). The impact of house prices on consumer credit: evidence from an internet bank. Journal of Money, Credit and Banking, 45(6), 1085-1115. https://doi.org/10.1111/jmcb.12045

Robstad, $\varnothing$. (2017). House prices, credit and the effect of monetary policy in Norway: evidence from structural VAR models. Empirical Economics, 54(2), 461-483.

https://doi.org/10.1007/s00181-016-1222-1 
Sá, F., \& Wieladek, T. (2015). Capital inflows and the U.S. housing boom. Journal of Money, Credit and Banking, 47(S1), 221-256. https://doi.org/10.1111/jmcb.12200

Setzer, R., van den Noord, P., \& Wolff, G. B. (2011). Heterogeneity in money holdings across euro area countries: the role of housing. European Journal of Political Economy, 27(4), 764-780. https://doi.org/10.1016/j.ejpoleco.2011.04.003

Sheiner, L. (1995). Housing prices and the savings of renters. Journal of Urban Economics, 38(1), 94-125. https://doi.org/10.1006/juec.1995.1024

Simionescu, M., Balcerzak, A. P., Bilan, Y., \& Kotásková, A. (2018). The impact of money on output in Czech Republic and Romania. Journal of Business Economics and Management, 19(1), 20-41. https://doi.org/10.3846/Jbem.2018.1480

Su, C.-W., Yao, Z.-L., \& Chang, H.-L. (2016). The relationship between output and asset prices: a time and frequency - varying approach. Theoretical \& Applied Economics, 23(1), 57-76.

Su, C.-W., Wang, X.-Q., Tao, R., \& Chang, H.-L. (2019). Does money supply drive housing prices in China?. International Review of Economics and Finance, 60, 85-94. https://doi.org/10.1016/j.iref.2018.12.013

Taylor, J. B. (2009). The need to return to a monetary framework. Business Economics, 44(2), 63-72. https://doi.org/10.1057/be.2009.1

Thornton, D. L. (2010). The downside of quantitative easing. Economic Synopses, 2010(34). https://doi.org/10.20955/es.2010.34

Tiwari, A. K., Albulescu, C. T., \& Gupta, R. (2016). Time-frequency relationship between US output with commodity and asset prices. Applied Economics, 48(3), 227-242. https://doi.org/10.1080/00036846.2015.1076154

Torrence, C., \& Compo, G. P. (1998). A practical guide to wavelet analysis. Bulletin of the American Meteorological Society, 79(1), 61-78. https://doi.org/10.1175/1520-0477(1998)079<0061:APGTWA>2.0.CO;2

Weale, M., \& Wieladek, T. (2016). What are the macroeconomic effects of asset purchases? Journal of Monetary Economics, 79, 81-93. https://doi.org/10.1016/j.jmoneco.2016.03.010

White, M. (2015). Cyclical and structural change in the UK housing market. Journal of European Real Estate Research, 8(1), 85-103. https://doi.org/10.1108/jerer-02-2014-0011

Willen, P. (2015). Discussion of Arslan, Guler, and Taskin. Journal of Money, Credit and Banking, 47(S1), 171-174. https://doi.org/10.1111/jmcb.12197

Zhang, C. (2013). Money, housing, and inflation in China. Journal of Policy Modeling, 35(1), 75-87. https://doi.org/10.1016/j.jpolmod.2012.04.006 


\section{APPENDIX}

Table 1A. House Price data (source: BIS Residential Property Price database (http://www.bis.org/statistics/pp.htm)

\begin{tabular}{|c|c|c|}
\hline Country & Information on the adjusted property prices & Source \\
\hline Australia & $\begin{array}{l}\text { From } 2003 \text { Q3 onward: Residential property prices, all } \\
\text { dwellings ( 8 cities), Pure price, NSA;1986 Q3 - 2003 Q2: } \\
\text { Residential property prices, all detached houses (8 cities), } \\
\text { pure price, NSA; } 1970 \text { Q1 - } 1986 \text { Q2: Median dwelling } \\
\text { prices, capital cities }\end{array}$ & $\begin{array}{l}\text { Australian Bureau Of } \\
\text { Statistics; Real Estate } \\
\text { Institute of Australia }\end{array}$ \\
\hline Canada & $\begin{array}{l}\text { From } 2005 \text { Q1 onwards: MLS Composite index; Between } \\
\text { 1980 Q1 - 2004 Q4: National residential average price, } \\
\text { NSA.; } 1970 \text { Q1 - 1979 Q4: Average price of existing } \\
\text { homes }\end{array}$ & $\begin{array}{l}\text { CREA The Canadian } \\
\text { Real Estate Association; } \\
\text { Multiple Listing Service }\end{array}$ \\
\hline Denmark & $\begin{array}{l}\text { From } 2002 \text { Q1 onwards All types of dwellings in the } \\
\text { country as a whole; } 1970 \text { Q1 - } 2002 \text { Q3: Residential } \\
\text { property prices, single-family houses, pure price, NSA }\end{array}$ & Statistics Denmark \\
\hline Euro area & $\begin{array}{l}\text { All Types Of New And Existing Dwellings In The Whole } \\
\text { Country }\end{array}$ & $\begin{array}{l}\text { BIS: Residential property } \\
\text { prices, selected, nominal, } \\
2010=100\end{array}$ \\
\hline Japan & $\begin{array}{l}\text { From } 2008 \text { Q2 onwards Residential property prices, all } \\
\text { dwellings, piure price, NSA; } 1955 \text { Q1 - } 2008 \text { Q1: Land } \\
\text { prices, residential, urban areas, per m², NSA }\end{array}$ & $\begin{array}{l}\text { Ministry of Land } \\
\text { Infrastructure, } \\
\text { Transport and Tourism; } \\
\text { Japan Real Estate Agency }\end{array}$ \\
\hline $\begin{array}{l}\text { New } \\
\text { Zealand }\end{array}$ & $\begin{array}{l}\text { From } 1979 \text { Q4 onwards: Residential property prices, } \\
\text { all dwellings, per dwelling, NSA; } 1970 \text { Q1 - 1979 Q3: } \\
\text { Quarterly house price index main urban areas; quotable } \\
\text { value New Zealand Limited }\end{array}$ & $\begin{array}{l}\text { Statistics Norway; } \\
\text { Quotable Value New } \\
\text { Zealand Limited }\end{array}$ \\
\hline Norway & $\begin{array}{l}\text { From } 1992 \text { Q1 onwards: Residential property prices,all } \\
\text { (only existing from 2012) dwellings, pure price, NSA; } \\
1970 \text { Q1 - 1991 Q4: House prices, from O Eitrheim and } \\
\text { S Erlandsen, House price indices for Norway, 1819-2003, } \\
\text { pp 349-376, 2004. }\end{array}$ & $\begin{array}{l}\text { Statistics Norway; } \\
\text { Norges Bank }\end{array}$ \\
\hline $\begin{array}{l}\text { South } \\
\text { Africa }\end{array}$ & $\begin{array}{l}\text { 1966 Q1 - } 2000 \text { Q4: Residential property prices, all } \\
\text { middle segment dwelling, per dwellings; From } 2001 \text { Q1: } \\
\text { Residential property prices all dwellings }\end{array}$ & $\begin{array}{l}\text { Absa Group, } \\
\text { First National Bank }\end{array}$ \\
\hline Sweden & $\begin{array}{l}\text { From } 2005 \text { Q1 onwards: All types of dwellings in the } \\
\text { country as a whole; } 1986 \text { Q1 - } 2004 \text { Q4: Residential } \\
\text { property prices, all owner-occupied houses, per dwelling, } \\
\text { NSA; 1970 Q1 - } 1985 \text { Q4: Index of owner-occupied one- } \\
\text { and two-dwelling buildings }\end{array}$ & Statistics Sweden \\
\hline Switzerland & $\begin{array}{l}\text { From } 1970 \text { Q1 onwards: Unweighted average of owner } \\
\text { occupied flats and houses in the country as a whole }\end{array}$ & Swiss National Bank \\
\hline $\begin{array}{l}\text { United } \\
\text { Kingdom }\end{array}$ & $\begin{array}{l}\text { From } 2005 \text { Q1 onwards: Residential property prices, } \\
\text { all dwellings (ONS), per dwelling; } 1968 \text { Q2 - 2004 Q4 } \\
\text { Residential property prices, all dwellings (ONS), per } \\
\text { dwelling (historical data) }\end{array}$ & $\begin{array}{l}\text { Office For National } \\
\text { Statistics }\end{array}$ \\
\hline $\begin{array}{l}\text { United } \\
\text { States }\end{array}$ & $\begin{array}{l}\text { From } 1975 \text { Q4 onwards: Residential property prices, } \\
\text { existing dwellings, per dwelling, SA; 1970 Q1 - } 1975 \text { Q3: } \\
\text { Average sale price of existing single-family homes }\end{array}$ & $\begin{array}{l}\text { Corelogic; } \\
\text { National Association } \\
\text { of Realtors }\end{array}$ \\
\hline
\end{tabular}

Note: For euro area $2010=100$, while data are available between 1Q 1980 and 4Q 2016. The data are nominal residential property prices, index $(1995=100)$. 
Table 2A. M3 and M2 data (source: own work)

\begin{tabular}{|c|c|c|c|c|}
\hline \multirow[b]{2}{*}{ Country } & \multicolumn{2}{|l|}{ M3 } & \multicolumn{2}{|l|}{ M2 } \\
\hline & Availability/additional information & Source & $\begin{array}{c}\text { Availability/additional } \\
\text { information }\end{array}$ & Source \\
\hline US & 1Q $1970-$ 4Q 2016 & IMF末 & 1Q $1970-4 Q 2016$ & IMF \\
\hline $\mathrm{AU}$ & 1Q $1970-4 Q 2016$ & FRED & 1Q $1970-4 Q 2016$ & FRED \\
\hline $\mathrm{CA}$ & 1Q 1970 - 4Q 2016 & IMF & $\begin{array}{l}\text { 1Q } 1970-4 Q 2016, \\
\text { Alternate Definition } 2 \\
\text { for Canada }\end{array}$ & FRED \\
\hline NZ & 1Q 1970 - 4Q 2016 & FRED & 1Q $1994-4 Q 2016$ & IMF \\
\hline $\mathrm{JP}$ & 4Q 1971 - 4Q 2016 & IMF & 1Q $1970-4 Q 2016$ & IMF \\
\hline UK & $\begin{array}{l}\text { 1Q } 1970 \text { - 4Q 2016, Broad Money (Break } \\
\text { Adjusted) }\end{array}$ & $\mathrm{BoE}$ & 3Q 1982 - 4Q 2016 & FRED \\
\hline $\mathrm{NO}$ & $\begin{array}{l}\text { 1Q } 1970 \text { - 4Q 2016, The FRED data in } \\
\text { millions from 1Q } 1993 \text { to 4Q } 2016 \text { were } \\
\text { recalculated back with the FRED M3's } \\
\text { growth rate for Norway (previous period) } \\
\text { to obtain earlier series from 1Q1970 to 4Q } \\
1992 .\end{array}$ & FRED & 1Q $1970-4 Q 2016$ & FRED \\
\hline SE & 1Q 1970 - 4Q 2016 & IMF & 1Q $1998-4 Q 2016$ & IMF \\
\hline $\mathrm{DK}$ & 1Q 1970 - 4Q 2016 & FRED & 1Q 1991 - 4Q 2016 & IMF \\
\hline $\mathrm{CH}$ & $\begin{array}{l}\text { 4Q } 1971 \text { - 4Q 2016, M3 data from } \\
\text { IMF since 1Q 1984 until 4Q } 2016 \text { were } \\
\text { recalculated backwards with the growth } \\
\text { rates received from FRED's data in millions. }\end{array}$ & $\begin{array}{l}\text { IMF, } \\
\text { FRED }\end{array}$ & 1Q $1984-4 Q 2016$ & IMF \\
\hline $\mathrm{ZA}$ & 1Q 1970 - 4Q 2016 & IMF & 1Q $1970-4 Q 2016$ & IMF \\
\hline EA & 1Q $1970-4 Q 2016$ & FRED & 1Q $1984-4 Q 2016$ & FRED \\
\hline
\end{tabular}

Note: In the US, data for the monetary aggregate M3 are available until 4Q 2005 because Fed has ceased their publication. Since then they are extrapolated with the growth rate of a broad money index from Monthly Monetary and Financial Statistics of OECD. 